\title{
Seismic and gravity data reveal Tertiary interplate subduction in the Bellingshausen Sea, southeast Pacific
}

\author{
Karsten Gohl* \\ Frank Nitsche \\ Heinz Miller \\ Alfred Wegener Institute for Polar and Marine Research, P.O. Box 120161, D-27515 Bremerhaven, Germany
}

\begin{abstract}
Satellite gravity data reveal extraordinary lineations in the gravity field of the western Bellingshausen Sea. Major north-south-striking gravity anomalies west of Peter I Island and between the island and the De Gerlache Seamounts raise questions of the deep crustal structure and tectonic events in that part of the Antarctic plate. As part of two cruises in the Bellingshausen and Amundsen seas with RV Polarstern in 1994 and 1995, we acquired multichannel seismic records and shipborne gravity data across the gravity anomalies. The combined data set shows strong evidence for a converging event within the oceanic crust, including a subducted crustal segment and possibly accreted sediments on top of the downgoing basement. West and east of the basement step and diffraction zone, the seismic sections indicate normally developed oceanic crust with moderate basement undulations. The sequence of undisturbed sediments on top of the compressional structure suggests a tectonic event between 50 and $13 \mathrm{Ma}$, while relative motion between the Antarctic-Bellingshausen plate and the Phoenix plate had already begun in the Late Cretaceous. We suggest that this convergent tectonic structure could have developed as an early Tertiary transcurrent plate boundary to accommodate the relative motion between the AntarcticBellingshausen plate and the southward migrating and subducting Phoenix plate.
\end{abstract}

\section{INTRODUCTION}

Shaded images of the gravity field derived from GEOSAT, SEASAT, and ERS-1 satellite altimetry data have become an extremely valuable tool for designing marine geophysical experiments. In particular, there was a lack of detailed knowledge about the sea-floor topography of the remote polar regions and tectonic lineations associated with them. Patterns and lineations of gravity anomalies of recently published satellite gravity maps from the circum-Antarctic oceans help to define plate tectonic boundaries and provide benchmarks for describing the ocean-floor structure and history (Marks and McAdoo, 1992; Sandwell and Smith, 1992).

Our region of interest, the Bellingshausen and Amundsen seas, off West Antarctica (Fig. 1), is one of the less-explored southern ocean basins, having sparse geophysical coverage (e.g., Herron and Tucholke, 1976; Tucholke, 1977; Kimura, 1982; Cunningham et al., 1994; Rebesco et al., 1996) due to its remoteness and severe weather and ice conditions. Identifications of magnetic stripe patterns northwest of the central and northern Antarctic Peninsula revealed that the previously existing Phoenix plate subducted beneath the continental margin until the Phoenix-Pacific and Phoenix-Farallon spreading ridges collided with the trench (Barker, 1982). After the eastwardmigrating ridge-trench collision along the Ant-

*Present address: Macquarie University, School of Earth Sciences, Sydney NSW 2109, Australia. E-mail: kgohl@brunhes.es.mq.edu.au. arctic Peninsula during the Cenozoic, the subducting process ceased and the continental margin became a passive one. The age of the southeast Pacific basin determined from available magnetic data suggests that the former convergent margin extended from the northernmost Antarctic Peninsula to about long $85^{\circ} \mathrm{W}$. Owing to the lack of reliable magnetic data west of long $85^{\circ} \mathrm{W}$, a former subduction zone along the margin of western Ellsworth Land and eastern Marie Byrd Land can only be assumed, not verified.

Major north-south-striking satellite gravity anomalies crossing the western Bellingshausen Sea were first described by Marks and McAdoo (1992). As part of two larger geoscientific surveys of the southeast Pacific-Antarctic region, we investigated the high-amplitude gravity anomaly west of Peter I Island, herein named the Bellingshausen gravity anomaly, by the means of multichannel seismic (MCS) and shipborne gravity recordings from the RV Polarstern, cruises ANTXI/3 (1994) and ANT-XII/4 (1995). The objective of the geophysical investigations was primarily to gain knowledge of the deep oceanic crustal structure causing the anomalously large amplitudes along the Bellingshausen gravity anomaly in a strike direction about $45^{\circ}$ oblique to that of the major southeastern Pacific fracture zones such as the Udintsev and Tharp fracture zones. In this study we show the seismic and gravity data leading to a model of a converging oceanic crustal block with an associated transpression and partial subduction along the north-south-striking gravity anomaly in the Bellingshausen Sea.

\section{EXPERIMENTAL SETUP}

Gravity data derived from satellite altimetry (Sandwell and Smith, 1992) served as a base for choosing the location of seismic profiles crossing the Bellingshausen gravity anomaly (Fig. 1). The Bellingshausen gravity anomaly extends from the shelf break to about latitude $66^{\circ} \mathrm{S}$, where its low-amplitude segment intersects with the De Gerlache Seamount group. A second near-linear gravity anomaly system, herein named De Gerlache gravity anomaly, extends from Peter I Island across the De Gerlache Seamounts to about lat $62^{\circ} \mathrm{S}$. Shipborne gravity data were recorded continuously and supplemented the available satellite gravity data in terms of exact amplitudes and spatial resolution. The seismic profiles AWI-94041 and AWI-94043 cross the southern segment of the Bellingshausen gravity anomaly, where the amplitude of the free-air gravity anomaly reaches its maximum absolute value of about $120 \mathrm{mgal}$ relative to the oceanic crust west and east of the Bellingshausen gravity anomaly. With profiles AWI-95200, AWI-95201, and AWI-95210 we intend to resolve the deeper crustal structure of the Bellingshausen gravity anomaly toward its northern termination and the crust beneath the De Gerlache gravity anomaly.

Whereas seismic profiles AWI-94041 and AWI-94043 were recorded with a $600 \mathrm{~m}$ streamer, we operated a streamer of $2400 \mathrm{~m}$ active length for profiles AWI-95200, AWI-95201, and AWI-95210. Both streamers recorded 96 channels. An array of eight air guns with a total volume of $24 \mathrm{~L}$ served as source for all profiles. Shot interval was $15 \mathrm{~s}$ with a recording length of 


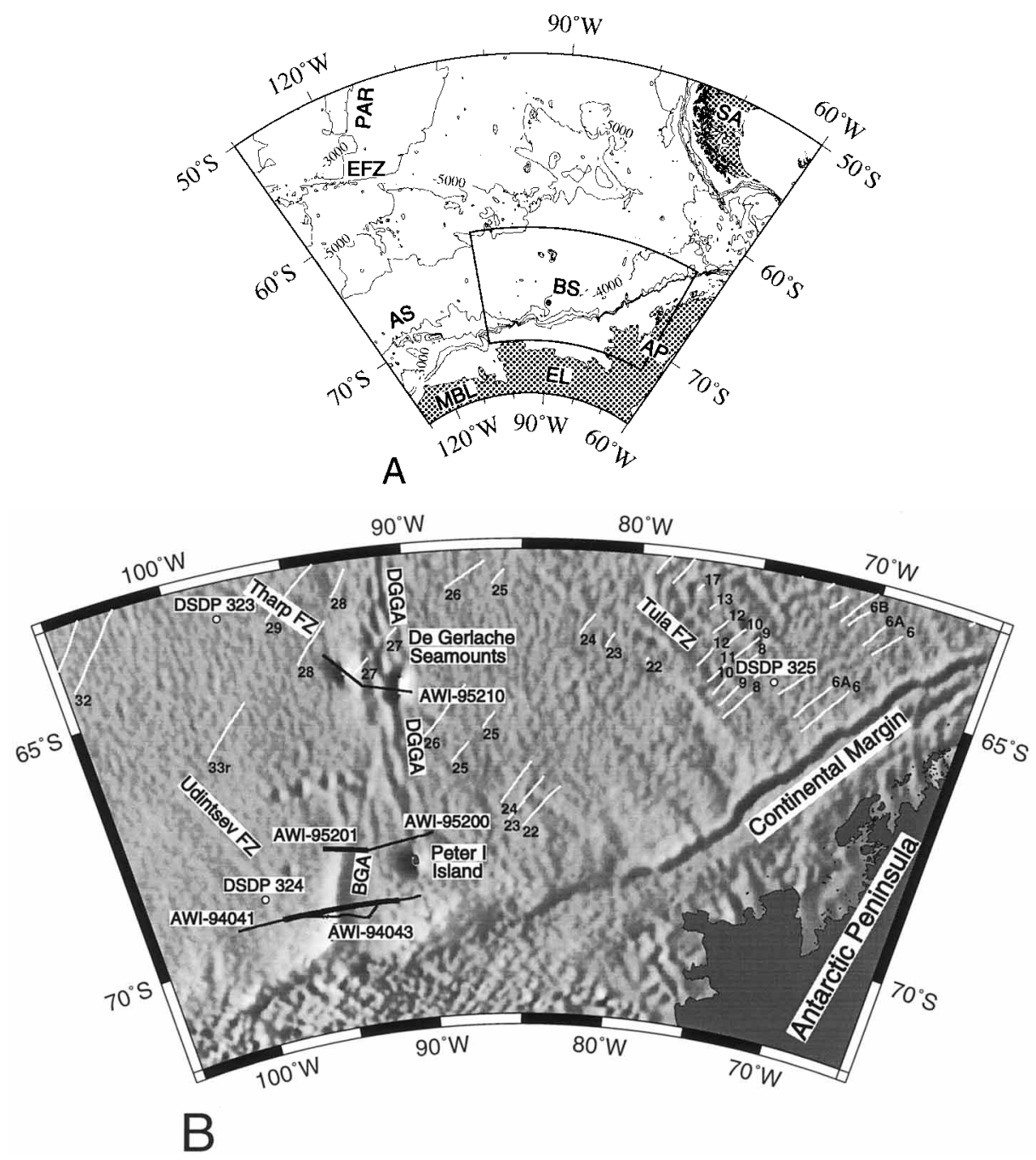

Figure 1. A: Regional overview map of southeast Pacific with bathymetry from ETOPO-5 data set (1000 m contour interval). Abbreviations denote South America (SA), Antarctic Peninsula (AP), Ellsworth Land (EL), Marie Byrd Land (MBL), Bellingshausen Sea (BS), Amundsen Sea (AS), Pacific-Antarctic Ridge (PAR), and Eltanin fracture zone (EFZ). B: Shaded satellite gravity map (Sandwell and Smith, 1992) of Bellingshausen and Amundsen seas, off West Antarctica, with locations of multichannel seismic (MCS) profiles across north-south-striking gravity anomalies. MCS profiles were acquired during RV Polarstern cruises ANT-XI/3 in 1994 and ANT-XII/4 in 1995 (thin lines). Central parts of profile AWI-94041 and profile AWI-95201 cross Bellingshausen gravity anomaly and are shown in Figures 2 and 3 (bold lines). Magnetic lineations (white lines) are from Cande et al. (1989). Other labels denote De Gerlache gravity anomaly, dominant fracture zones (FZ), and Deep Sea Drilling Project (DSDP) sites.

$12 \mathrm{~s}$. We processed the data within a conventional processing stream that includes trace editing, sorting, and binning to $25 \mathrm{~m}$ common midpoint spacing, velocity analysis, stacking, and filtering.

\section{RESULTS}

The seismic profiles across the Bellingshausen gravity anomaly (Figs. 2 and 3 ) show the sediment-basement boundary (oceanic layer 1-2) covered by horizontally stratified largely undisturbed sedimentary sequences, having a total thickness between 2 and $3 \mathrm{~km}$. A dominant feature of the southern profiles AWI-94041 and AWI-94043 is a topographic high rising from the 4300-m-deep sea floor to about $3800 \mathrm{~m}$ at its peak, having a steeper flank on its western side. Sedimentary layering parallels the gradual eastern slope, indicat- are used for depth estimation. In all profiles we observe the east-dipping basement to about 9-9.5 s. If we assume that the bottom of stratified layering east of the gravity minimum is the top of a basement that rises westward to a higher topographic location, the total vertical basement offset amounts to a minimum of 7-8 $\mathrm{km}$ on profile AWI94041. The zone within the basement step is characterized by a chaotic, highly diffractive reflection pattern that could easily lead to the assumption that this zone consists of fractured oceanic basement. However, the presence of a large-amplitude gravity minimum above the west flank of this diffractive body argues against basement, and for a low-density body of unstratified sediments.

Harsh weather conditions and technical circumstances made it almost impossible to record Moho reflections, except for a few locations along profiles AWI-95200 and AWI-95201. In this part of the Bellingshausen Sea, we can assume a crustal thickness of 9-12 km.

\section{CONVERGENCE MODEL AND ITS IMPLICATION}

The superposition of MCS recordings and shipborne gravity data allowed us to construct a well constrained two-dimensional gravity model across the Bellingshausen gravity anomaly along profile AWI-94041 (Fig. 4) by implementing the observed structural boundaries from the MCS data into the model. Published densities for typical oceanic layers were used. Although a crustmantle boundary was not clearly observed along profiles AWI-94041 and AWI-94043, we assumed a dipping Moho similar in depth and dip angle to an assumed Moho reflection observed in profile AWI-95201 (Fig. 3B). The large free-air gravity gradient of about $3 \mathrm{mgal} / \mathrm{km}$ between the minimum of $-88 \mathrm{mgal}$ and the maximum of +35 mgal can only be modeled by two juxtaposed bodies of large density contrasts with a deep-reaching contact between them. We implemented a low average density of $2.6 \mathrm{~g} / \mathrm{cm}^{3}$ for the seismically diffractive body above the east-dipping basement. Although a clear boundary between this body and the basement to the east is not observed in the seismic data, the gravity gradient places a strong constraint on a near-vertical boundary. The east-dipping basement and Moho reflections are indications for a downgoing slab of oceanic crust, causing the large-wavelength component of the gravity anomaly.

Lineated marine gravity anomalies of such large amplitude are mainly observed along transform faults and subduction zones (McAdoo and Marks, 1992; Sandwell and Smith, 1992), excluding the transition zones from oceanic to continental crust on passive margins. We can exclude a classical oceanic transform or transcurrent fault, because neither the Bellingshausen gravity anomaly nor the De Gerlache gravity anomaly align to an active or former spreading Ridge system. The satellite gravity image delineates the northwest- 


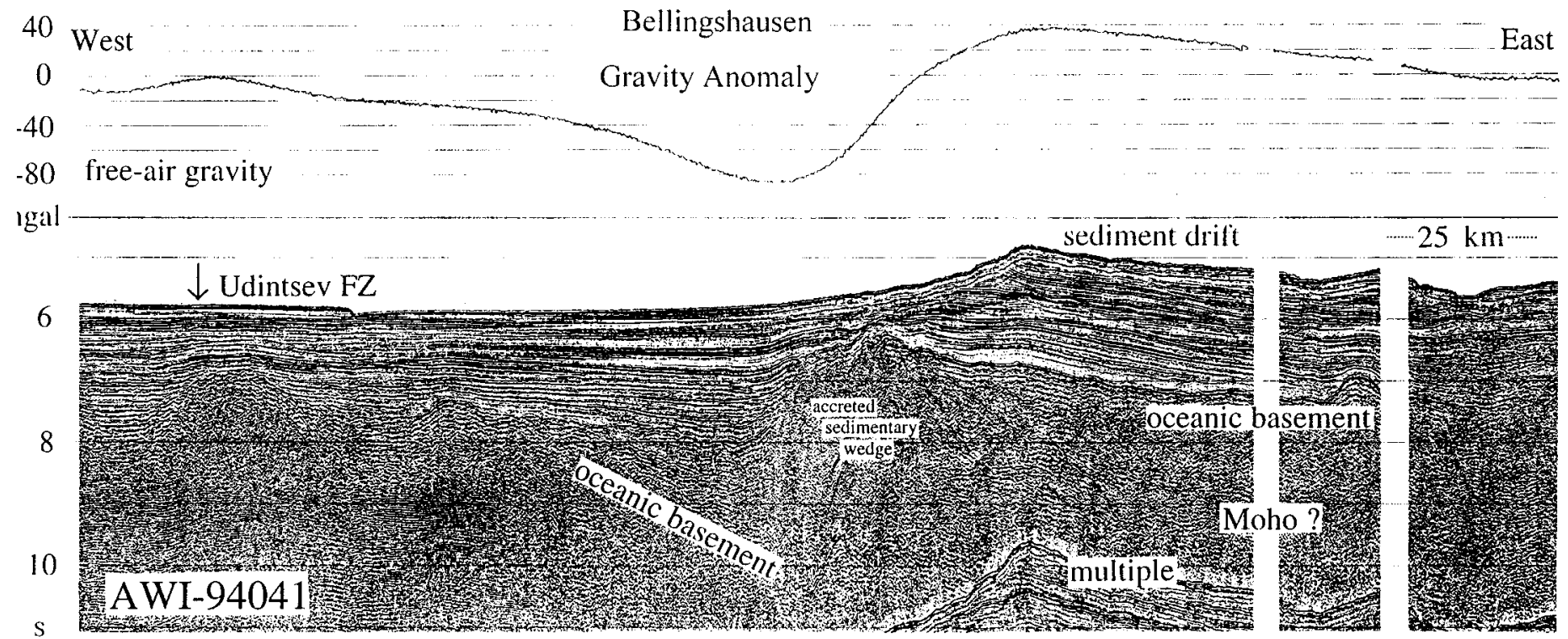

Figure 2. Central part of seismic profile AWI-94041 across southern Bellingshausen gravity anomaly shows east-dipping, submerged oceanic basement with zone of highly diffractive reflection pattern on top. Vertical basement offset amounts to minimum of 7-8 km. Ocean-bottom currents formed sediment drift expressed as large topographic rise. High-frequency arrivals at about $9 \mathrm{~s}$ and more are multiples generated from previous shots.

southeast-striking Udintsev and Tharp fracture zones, which continue to the Pacific-Antarctic Ridge (Mayes et al., 1990; McAdoo and Marks, 1992; Sandwell and Smith, 1992). The Udintsev fracture zone terminates at the intersection of the Bellingshausen gravity anomaly with the continental margin, and the Tharp fracture zone intersects the De Gerlache gravity anomaly. An extension of the Tharp fracture zone east of the De Gerlache gravity anomaly is uncertain.
The steeply east-dipping slab of oceanic crust underneath the Bellingshausen gravity anomaly, however, indicates a compressional stress that forced the western crust to partially subduct beneath the eastern crust. Although the seismic data do not provide a complete image of the downgoing slab, modeling results of gravity data indicate a maximum depth of about 13 to $16 \mathrm{~km}$ beneath the sea floor. We interpret the seismically diffractive midcrustal body of presumed low density
A

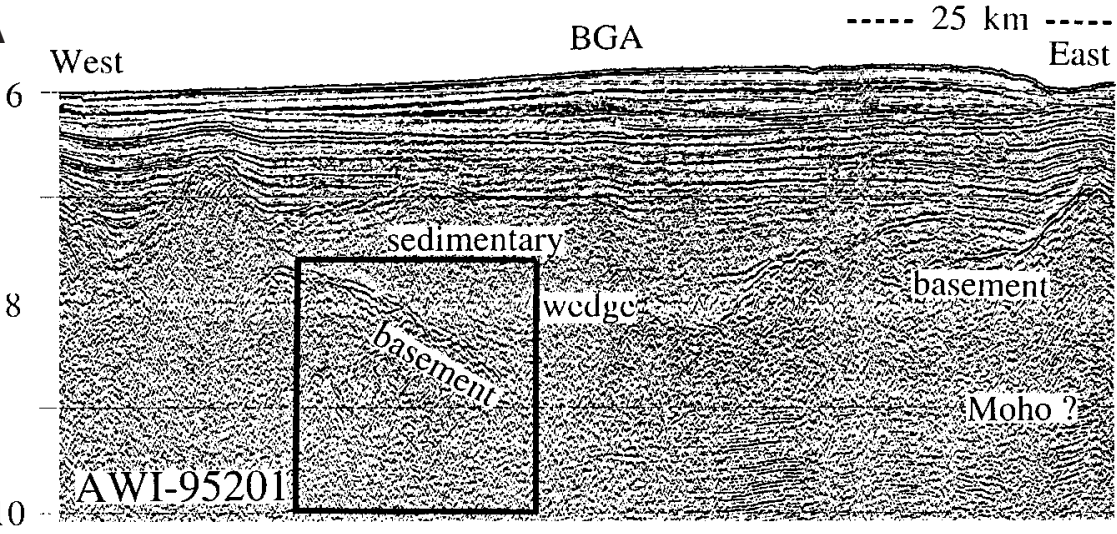

B

Figure 3. A: Seismic profile AWI-95201 across central Bellingshausen gravity anomaly. Central part exhibits unstratified wedge on top of strongly reflective east-dipping basement. Bands of high-frequency arrivals beginning at about $9 \mathrm{~s}$ are artifacts (multiples) from previous shots. B: Blow-up window shows coherency-filtered section with improved image of east-dipping presumed Moho.

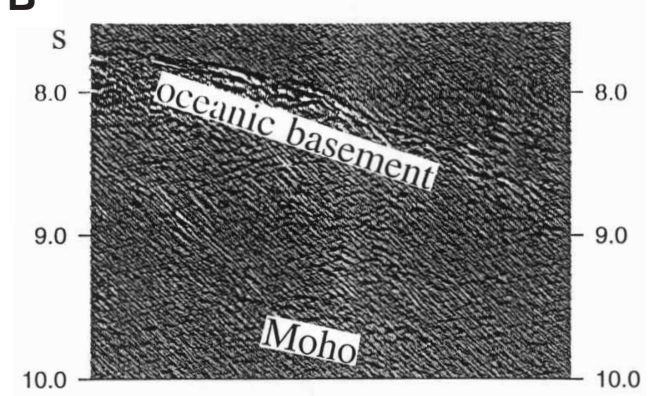

above the dipping basement slab as a zone of accreted and extremely deformed sediments that formed a wedge between the downgoing plate and the overriding basement. It is very likely that there was a strong strike-slip or transpressional component in the motion of the two crustal blocks, if we assume the main stress propagating along the strike of the oceanic fracture zones. The stress vector is then about $45^{\circ}$ to the strike direction of the Bellingshausen gravity anomaly.

At what time did the Bellingshausen gravity anomaly and De Gerlache gravity anomaly form? Sparsely mapped magnetic anomalies of the crust east of the Bellingshausen gravity anomaly and around the northern segment of the De Gerlache gravity anomaly range from anomaly 23 to 28 (51-64 Ma) (Cande et al., 1989; Cande and Kent, 1992). The relatively undisturbed sedimentary cover of $1-2 \mathrm{~km}$ thickness (1-1.5 s) across the Bellingshausen gravity anomaly on profile AWI95201 (Fig. 3A) provides a very uncertain age constraint. Sedimentation rates vary from 4 to $8 \mathrm{~cm} / \mathrm{k}$.y. for the Bellingshausen Basin, according to the Deep Ocean Drilling Project core analyses (Hollister and Craddock, 1976), resulting in a minimum age range for tectonic deformation between 13 and 50 Ma. Recently collected dredge samples of alkaline basalts from the De Gerlache Seamounts yield ages of about 20-21 Ma (B. Hagedorn, personal commun., 1996). Reported ages of the alkaline volcanism and growth of Peter I Island are even younger and range from about $13 \mathrm{Ma}$ (Bastien et al., 1976) to $0.1 \mathrm{Ma}$ (Prestvik et al., 1990).

Tectonic reconstruction models of the southeast Pacific describe the relative motion of the Antarctic-Bellingshausen and Phoenix plates from Late Cretaceous to early Tertiary (Stock and Molnar, 


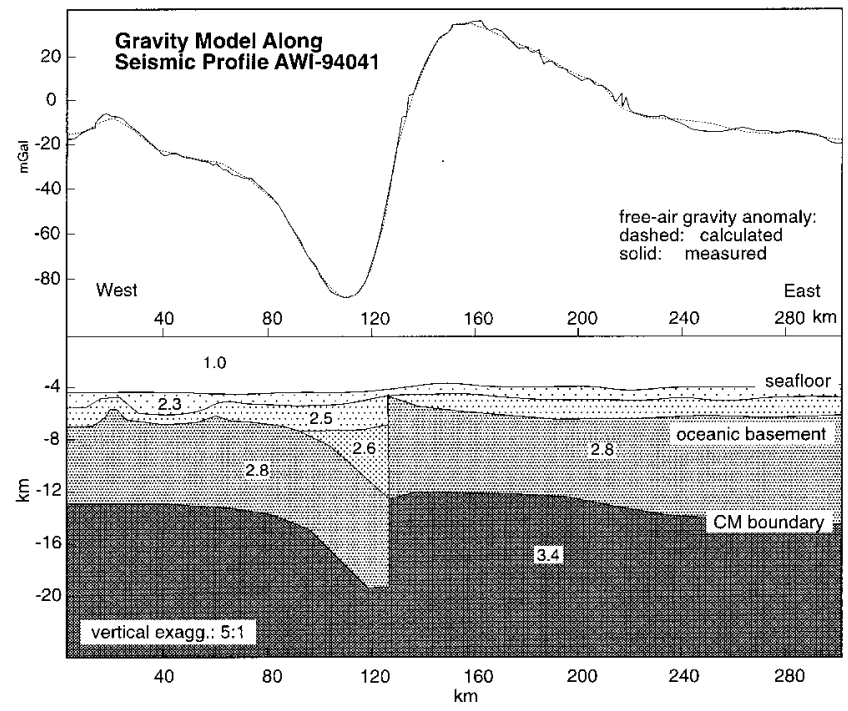

1987; Mayes et al., 1990). After the separation of the Pacific-Antarctic Ridge into dual spreading centers, the Phoenix-Pacific Ridge migrated toward the Antarctic continental margin, where it subsequentially collided with the trench. We propose that the structures beneath the Bellingshausen and De Gerlache gravity anomalies might represent the tectonic expression of an early Tertiary interplate boundary between the Antarctic-Bellingshausen plate and the Phoenix plate. Such a transcurrent plate boundary must have existed to accommodate the plate motion between the Antarctic-Bellingshausen plate and the Phoenix plate. More magnetic data are needed in the vicinity of the gravity anomalies to test this hypothesis.

The alkaline basalts of Peter I Island and the De Gerlache Seamounts might be associated with late Cenozoic basalt provinces on Marie Byrd Land and Thurston Island (LeMasurier and Rex, 1989; Hole et al., 1994; B. Hagedorn, 1996, personal commun). However, lithospheric weakening after strike slip and transpressional fracturing of the oceanic crust along the De Gerlache and Bellingshausen gravity anomaly systems has probably controlled their extrusion.

\section{CONCLUSIONS}

Plate convergence and partial subduction within the oceanic crust are observed in recent seismic and marine gravity data from the Bellingshausen Sea, off the continental margin of West Antarctica. Seismic profiling and modeling of gravity data across one of the prominent northsouth-striking gravity anomalies, the Bellingshausen gravity anomaly, show a submerged, eastdipping basement slab with an accreted sediment wedge on top. Images of satellite gravity data show that the Bellingshausen gravity anomaly and De Gerlache gravity anomaly intersect or
Figure 4. Two-dimensional gravity model across Bellingshausen gravity anomaly derived from shipborne gravity data along seismic profile AWI-94041. Seismic records provided layer boundaries for sedimentary section and basement surface. Crust-mantle (CM) boundary can be assumed from sparse Moho reflections of seismic profiles AWl-95200 and AWl-95201. Densities are in grams per cubic centimetres.

possibly terminate the Udintsev and Tharp fracture zones. We suggest that the tectonic structures beneath the anomalies represent an early Tertiary plate boundary between the Antarctic-Bellingshausen plate and the southward migrating Phoenix plate. The relative motion between the two plates must have resulted in a transcurrent and partly convergent plate boundary.

\section{ACKNOWLEDGMENTS}

We are grateful to the captain and crew of the RV Polarstern, who were very supportive during the cruises ANT-XI/3 and ANT-XII/4. We also thank the members of the seismic teams, in particular Notker Fechner, Laszlo Oszko, and Olaf Haase, who contributed to data processing, modeling, and discussions. Comments of Steve Cande and an anonymous reviewer improved the manuscript. This is Alfred Wegener Institute publication no. 1176 .

\section{REFERENCES CITED}

Barker, P. F., 1982, The Cenozoic subduction history of the Pacific margin of the Antarctic Peninsula: Ridge crest-trench interactions: Geological Society of London Journal, v. 139, p. 787-801.

Bastien, T. W., Lehmann, E. K., and Craddock, C., 1976, The geology of Peter I Island, in Hollister, C. D., et al., Initial reports of the Deep Sea Drilling Project, Volume 35: Washington, D.C., U.S. Government Printing Office, p. 341-357.

Cande, S. C., and Kent, D. V., 1992, A new geomagnetic polarity time scale for the Late Cretaceous and Cenozoic: Journal of Geophysical Research, v. 97 , p. $13917-13951$

Cande, S. C., LaBrecque, J. L., Larson, R. L., Pitman, W. C., Golovchenko, X., and Haxby, W. F., 1989, Magnetic lineations of the world's ocean basins (map): Tulsa, Oklahoma, American Association of Petroleum Geologists, scale 1:27 400000 .

Cunningham, A. P., Larter, R. D., and Barker, P. F., 1994, Glacially prograded sequences on the Bell- ingshausen Sea continental margin near $90^{\circ} \mathrm{W}$ [abs.]: Terra Antarctica, v. 1, p. 267-268.

Herron, E. M., and Tucholke, B. E., 1976, Sea-floor magnetic patterns and basement structure in the southeastern Pacific, in Hollister, C. D., et al., Initial reports of the Deep Sea Drilling Project, Volume 35: Washington, D.C., U.S. Government Printing Office, p. 263-278.

Hole, M. J., Storey, B. C., and LeMasurier, W. E., 1994, Tectonic setting and geochemistry of Miocene alkalic basalts from the Jones Mountains, West Antarctica: Antarctic Science, v. 6, p. 85-92.

Hollister, C. D., and Craddock, C., 1976, Introduction, principal results-Leg 35, Deep Sea Drilling Project, in Hollister, C. D., et al., Initial reports of the Deep Sea Drilling Project, Volume 35: Washington, D.C., U.S. Government Printing Office, p. 5-14.

Houtz, R. E., 1974, Continental margin of Antarctica: Pacific-Indian sectors, in Burk, C. A., and Drake, C. L., eds, The geology of continental margins: New York, Springer Verlag, p. 655-658.

Kimura, K., 1982, Geological and geophysical survey in the Bellingshausen Basin, off Antarctica: Antarctic Record, no. 75, p. 12-24.

LeMasurier, W. E., and Rex, D. C., 1989, Evolution of linear volcanic ranges in Marie Byrd Land, West Antarctica: Journal of Geophysical Research, v. 94, p. 7223-7236.

Marks, K. M., and McAdoo, D. C., 1992, Gravity atlas of the Southern Ocean: Washington, D.C., U.S. Department of Commerce, National Geophysical Data Center, World Data Center-A for Marine Geology and Geophysics, Report MGG-7.

Mayes, C. L., Lawver, L. A., and Sandwell, D. T., 1990, Tectonic history and new isochron chart of the south Pacific: Journal of Geophysical Research, v. 95, p. 8543-8567.

McAdoo, D. C., and Marks, K. M., 1992, Gravity fields of the Southern Ocean from Geosat data: Journal of Geophysical Research, v. 97, p. 3247-3260.

Prestvik, T., Barnes, C. G., Sundvoll, B., and Duncan, R. A., 1990, Petrology of Peter I Øy (Peter I Island), West Antarctica: Journal of Volcanology and Geothermal Research, v. 44, p. 315-338.

Rebesco, M., Larter, R. B., Camerlenghi, A., and Barker, P. F., 1996, Giant sediment drifts on the continental rise west of the Antarctic Peninsula: Geo-Marine Letters, v. 16, p. 65-75.

Sandwell, D. T., and Smith, W. H. F., 1992, Global marine gravity from ERS-1, Geosat and Seasat reveals new tectonic fabric: Eos (Transactions, American Geophysical Union), v. 73, p. 133.

Stock, J., and Molnar, P., 1987, Revised history of early Tertiary plate motion in the south-west Pacific: Nature, v. 325, p. 495-499.

Tucholke, B. E., 1977, Sedimentation processes and acoustic stratigraphy in the Bellingshausen Basin: Marine Geology, v. 25, p. 209-230

Manuscript received September 3, 1996

Revised manuscript received December 31, 1996

Manuscript accepted January 8, 1997 